\title{
Preliminary Study on the Impact of Water Quality and Irrigation Practices on Soil Salinity and Crop Production, Gergera Watershed, Atsbi-Wonberta, Tigray, Northern Ethiopia
}

\author{
Yeshitela Bekele $^{1}$, Nata Tadesse ${ }^{2 *}$ and Bheemalingswara Konka ${ }^{2}$ \\ ${ }^{2}$ Department of Earth Science, College of Natural and Computational Sciences, P.O. Box 3066, \\ Mekelle University, Ethiopia (*amennata@gmail.com)
}

\begin{abstract}
Possible long term effects on soil salinity and crop production due to the quality of water and irrigation practices is assessed in an area in Gergera Watershed in Atsbi-Wonberta, Tigray, northern Ethiopia. Ten water samples collected from hand-dug wells and small household ponds, and thirty soil samples from different depths up to $\sim 100 \mathrm{~cm}$ were tested for various parameters such as TDS, $\mathrm{pH}$, anions and cations.

Data indicate that both water and soil in terms of quality are acceptable for irrigation purposes. However, at present the soil salinity is not a serious issue but the data suggests its possible increase with time as indicated by two samples. Some of the issues such as use of sprinklers, organic manure, blending, seasonal crops are discussed in the light of maintaining the required quality, proper utilization of soil and water resources, and for sustainable development.
\end{abstract}

Keywords: Watershed, Water quality, Soil quality, Hand-dug wells, House-hold Ponds.

\section{INTRODUCTION}

Groundwater use for irrigation, domestic and other purposes is increasing with increasing population globally and related food insecurity problems. In Africa, increasing agricultural productivity is a key to poverty reduction.

The average rate of irrigation development for the Sub-Saharan Africa region (40 countries) for the last 12 years was about 43,600 ha/year, which is an average of 1090 ha/year for each country. Some counties like Tanzania, Nigeria, Niger, Zimbabwe and South Africa have an average rate of development over 2000 ha/year (FAO, 2001).

According to Ethiopian Ministry of Water Resources (2001), Ethiopia is endowed with a huge potential of water resources, with 122 billon $\mathrm{m}^{3}$ annual surfaces runoff and 2.9 billion $\mathrm{m}^{3}$ of groundwater. However, the county's water resource has contributed little to the country's socioeconomic development. Like most African countries, Ethiopian economy is 
predominantly based on agriculture. The agricultural sector accounts for about $85 \%$ of the total employment and is the backbone and the mainstay of the economy (Siegfried et al., 1990).

Traditional irrigation in Ethiopia was practiced before centuries, while the Government of Ethiopia and the Dutch company known as HVA-Ethiopia sugar cane plantation started modern irrigation in the early 1950's. Various sources give different estimates of the irrigated area, but recent sources indicate that the area prepared for irrigation is nearly 290,000 ha in 2001, which is $11 \%$ of the economical irrigation potential of 3.5 million ha (FAO, 2005).

Like in other parts of the country, land is the source of livelihood in Tigray region. The economy of the region is based on agriculture with over $90 \%$ of the population is dependent on rain fed subsistence crop production (REST, 1997). The rainfall is quite erratic and unreliable. The land is also severely degraded due to unwise utilization of land resources. Soil erosion, soil nutrient depletion, and soil moisture stress are the major land degradation problems facing the region (Fitsum et al., 2002). As a result, the level of land productivity has declined at a faster rate and the region is not in a position to sustain the annual food demand of the people. To alleviate the issues of food insecurity in the country, the government of Ethiopia designed a national development plan based on a strategy called “Agricultural Development-led Industrialization”. The strategy aims at increasing agricultural productivity and production, and improving the rural living standards, which in_turn would increase the demand for goods and services and will lead to industrial development. This could be attained partly by promoting irrigation (Mekuria, 2003). As part of this strategy, the regional government as well as non-governmental organizations is engaged in water resource development activities both at household and community level to be used as a source of water for supplementary or complementary irrigation.

Currently, in Tigray, surface irrigation is the most predominant form of irrigation; it includes spring development, river diversion, flood spreading, micro-dams and pond systems. Groundwater is also developed in different parts of the region as source of water for irrigation. In the study area, with the introduction of water harvesting practices, groundwater and pond water utilization for irrigation by individual farmers has increased significantly.

As we know that availability of water by itself is not a guarantee for sustainable agricultural development, but its acceptability for different purposes like irrigation and domestic use is very important. Irrigation water quality problems may be caused by total mineral salts accumulation so that crops no longer produce well due to the development of sodic soils and accumulation of 
toxic levels of elements such as chloride, sodium and boron, these elements could make the land unproductive that incurs additional cost soil and water for leaching. At the same time nature of the soil and its quality with time is also important to sustain the required results. All soils contain some amount of soluble salts. Many of these salts act as sources of essential nutrients for healthy growth of plants. However, when the quantity of salts in the soil exceeds a particular value, growth, yield, and quality of most crops is adversely affected to a degree depending upon the kind and amount of salts present. Thus, over a period of time, salts that were previously distributed in the whole profile may selectively accumulate on the surface and give rise to saline soil. These are direct sources of salts on good quality lands. A good example is the use of high sodium-rich waters, which may lead to poor permeability and dispersion of soil. Salinity being one of the common problems in irrigation which can be built up with time though the rates varies on the salt content of the water used and can cause serious problems to soil quality and productivity. So, the issue of quality of water and soil is to be considered in the early stages of irrigated agricultural development programs and also is important in understanding and taking the correct management measures for long-term production.

With this background, the present paper tries to assess the quality of water (hand dug well and pond water) and soil; impact of water quality and irrigation practices on soil quality in terms of salinity; and suggests some techniques suitable for proper utilization of groundwater and surface water for irrigation both at household and community level in the Gergera watershed, Tigray.

\subsection{Study Area}

Gergera watershed is situated in Atsbi-Wonberta Woreda in Tabia Hayelom, Tigray, northern Ethiopia. Geographically, it is bounded between $39^{\circ} 30^{\prime}-39^{\circ} 45^{\prime} \mathrm{E}$ and $13^{\circ} 30^{\prime}-13^{\circ} 45^{\prime} \mathrm{N}$. It lies in the eastern part of Tigray, about $65 \mathrm{~km}$ NE of Mekelle, the regional capital of Tigray Regional State (Fig.1). Gergera watershed is located in the sub-tropical agro-climatic zone. Altitude wise, Atsbi Womberta district ranges from 1500-2800 m.a.s.l. The average daily temperature of the area is between $15^{\circ} \mathrm{C}$ and $30^{\circ} \mathrm{C}$. The mean annual rainfall of the area is about $529 \mathrm{~mm}$. The study area is drought prone with erratic, unevenly distributed rainfall and high run- off. The average rainfall in the area exceeds the potential evapotranspiration only in two months (July and August) of the year. Availability of adequate moisture is critical, in June 
at the start of the rainy season for germination; and in September for flowering, fruiting, crop production and tree growth.

The problem of land degradation in the area was high prior to 1997 due to energetic raindrop splash and high runoff. To overcome the problem of the resource degradation problem in the watershed, the District Bureau of Agriculture and Natural Resources has designed a watershed development program. With the full participation of the community, development strategies were mapped out and identified intervention measures to mitigate the consequences of land degradation, to rehabilitate degraded area and to increase land productivity. This resulted in the introduction of massive soil and water conservation structures like hillside terraces, trench bunds and re-forestation programs in the watershed area. Thus the area is now rehabilitated and is covered by increased biodiversity. This has not only helped to enhance the water resources in the area by raising groundwater table significantly but also has become a positive influential factor in irrigation development system.

Land use and land cover in the Gergera watershed is categorized as cultivated land, grassland, homestead and forest land. Major vegetable crops grown in the area are potatoes, hot pepper, onion, swiss chard and tomato. Considering the macro relief of Gergera watershed, physiographic nature ranges from almost flat to rugged mountain ranges. The corresponding slope range varies from $2 \%$ up to $80 \%$. The land use of the area in relation to slope is given in table 1.

Table 1. Land use pattern in the study area.

\begin{tabular}{|lll|}
\hline Land use & Physiography & Slope range (\%) \\
\hline Grazing land & Flat to undulating & $2-8$ \\
\hline Cultivated land & Flat land to rolling slope & $1-16$ \\
\hline Rockout crop & Sloppy & $16-80$ \\
\hline
\end{tabular}

There is a wide and large gulley that divides the watershed command area into two parts. The adjacent sloppy areas treated before eight years ago are now stabilized with integrated soil and water conservation technologies which are a good indicator of sustainable land management with sustainable resource use by the land users.

The area of study is drained by a number of intermittent streams that flow from east to west direction and the drainage pattern of the study area is dendrite type (Fig.1). In recent years, erratic and unreliable rainfall combined with the uneven topography, and the traditional 
agricultural practices, collectively are affecting the overall crop productivity in the area. Due to this the area faced food shortage even during the good rainy season and gradual decline in crop production and food in-security. However, the vegetation cover in the area has been improved with artificial plantation and area enclosure methods adopted with cut and carry system.

\subsection{Farming System}

The people of Gergera watershed exercise rain-fed, subsistence oriented mixed crop-livestock production farming system. The major crops and vegetables grown in the area are teff, barley, maize, wheat, bean, potatoes, hot pepper, onions, swisschards, lettuce and tomatoes. Recently, farmers are introducing fruit trees like Avocado, Guava, Banana and Papaya. The farmers of the study area use irrigation agriculture mainly using hand-dug wells, household farm ponds. To maximize yield, farmers use artificial fertilizer especially urea and di-amonium phosphates. These may contribute towards increase in the saline content or salinization process directly or indirectly. In the Gergera watershed there are about 500 households (above 80 thousand populations as per 1994 census) mostly involved in irrigation activity but with small land holdings.

\subsection{Geology}

The study area is dominated by Adigrat sandstone lithology. It forms part of the geological succession of northern Ethiopia and belong to Mesozoic age. Stratigraphically, the area is composed of basement Precambrian low grade metamorphic rocks and overlain by the younger Paleozoic Enticho sandstone and Adaga Arbi glacials units; Mesozoic Adigrat sandstone, Antalo limestone, Agula shale, Amba Aradom sandstone and alluvial deposits. Adigrat sandstone occupies the highest levels in the topography and is overlie the Paleozoic sedimentary rocks. The outcrops are mostly found in the south and southeastern parts of the watershed. There is a prominent escarpment in the area which consists of metamorphic rocks in the middle and colluvial deposits near the base.

\subsection{Soil}

Based on traditional classification, the dominant soil types of the study area are categorized as Hutsa (sandy), Baekel (loam) and Walka (clay), respectively. Major soils of the irrigated areas of the watershed are Vertisols, Cambisols, Leptosols and Alluvial soils. The dominant plant 
species in the watershed are bushes and shrubs, Acacia saligna, Dodonea visscosa, Eucalyptus species and trees like remnants of Olea europeana. Regenerated species are available in the plantation and area enclosures. Eucalyptus species, Acacia saligna and Dodonea in the plantation sites are part of biological soil and water conservation. These were introduced during the initial stages of the forest development program.

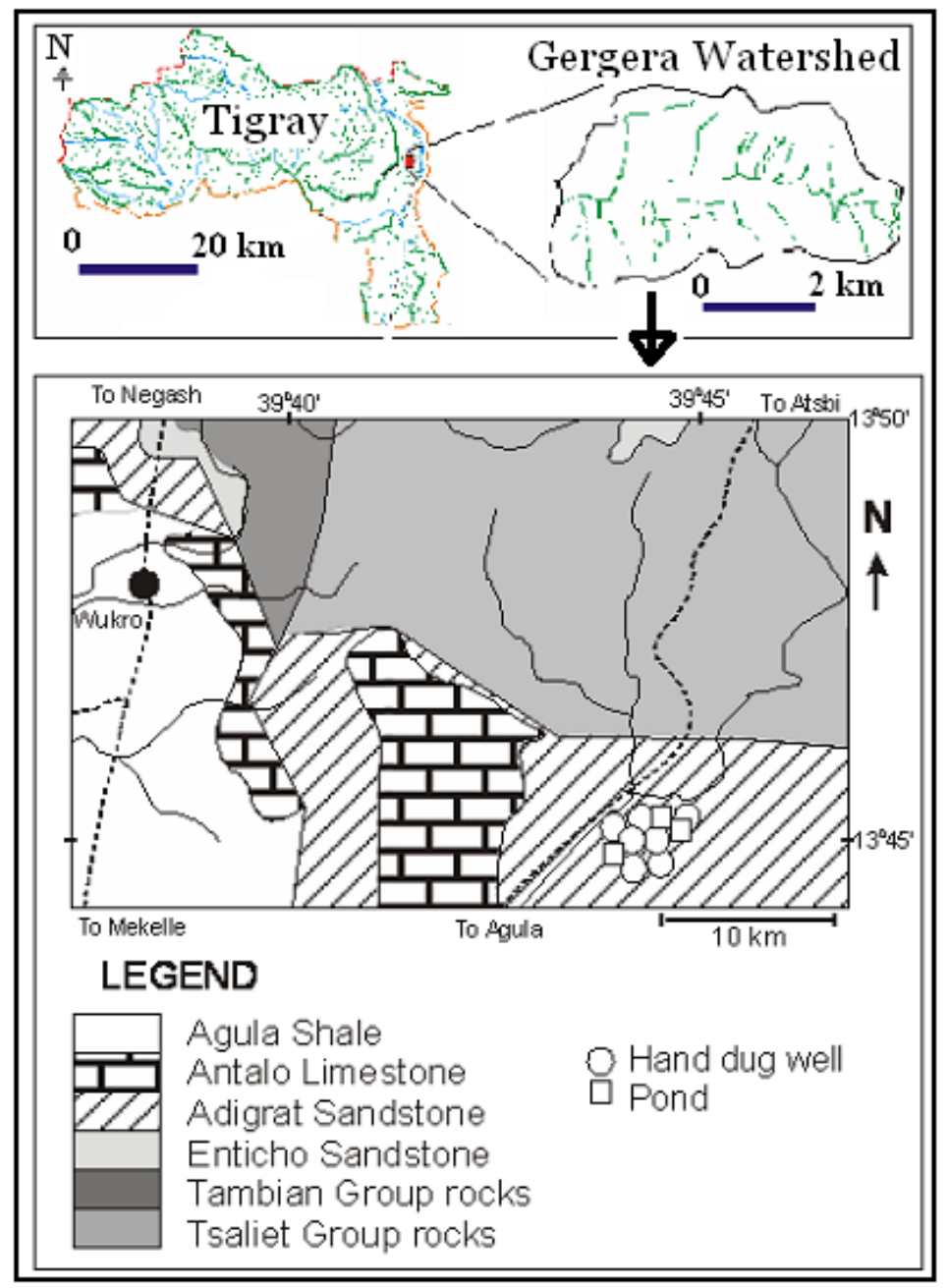

Figure 1. Geological and sample location map, Gergera Catchment, Wukro (Geological map after Geological Survey of Ethiopia, 1971).

\section{METHODOLOGY}

Gergera watershed boundary was delineated using topographic map. A reconnaissance survey was carried out in the watershed to record the total number of shallow hand- dug wells and household ponds present and that are used for irrigation purpose. There are about 70 shallow hand dug wells (HDW) and 30 house hold ponds (HHP) with water in the area. Out of 70 hand 
dug wells, 30 are lined with rock (HWR), 16 with cement (HWC) and 24 with clay (HWCL). The house hold ponds are mostly lined using plastic sheets (Fig.2B) (HHP) except in very few cases where cement (HHPC) is used. The hand-dug wells were constructed in 2003, while the ponds in 2004. About $10 \%$ of the wells and ponds were randomly selected for water sampling on the basis of $\mathrm{pH}$, color, turbidity, taste, odor and electrical conductivity (EC) measured in the field and the one in use. At the same sites, pits were excavated in the lands irrigated by hand dug wells and pond waters for depth-wise soil sampling. Samples are collected after monsoon so that water is available for irrigation particularly in the case of ponds.

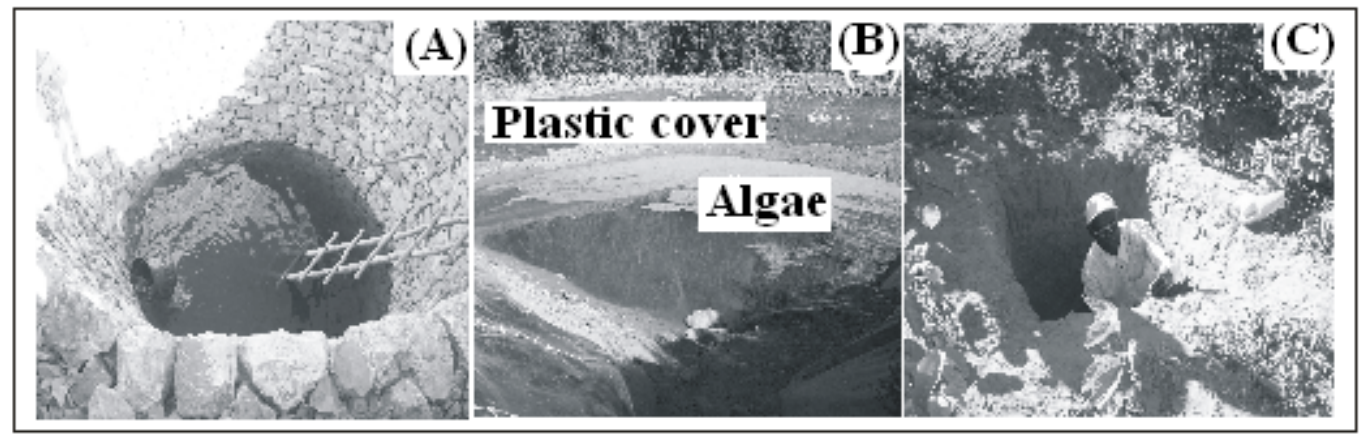

Figure 2. (A) Hand dug wells, (B) Household pond and (C) Profile pit soil sampling.

Table 2. Location of hand dug well lined with rock (HWR), cement (HWC), clay (HWCL) and household pond (HHP) with depth, Gergera catchment.

\begin{tabular}{|llllll|}
\hline Station & \multicolumn{1}{c}{ Sample } & $\boldsymbol{X}$ & $\boldsymbol{Y}$ & Altitude & Well depth (m) \\
\hline \multirow{3}{*}{$\begin{array}{l}\text { Gergera } \\
\text { (Wukro) }\end{array}$} & HWR 19 & 578026 & 1520016 & 2160 & 6 \\
\cline { 2 - 6 } & HWR 52 & 578484 & 1520252 & 2170 & 5 \\
\cline { 2 - 6 } & HWR 53 & 577264 & 1520039 & 2148 & 4 \\
\cline { 2 - 6 } & HWCL 6 & 578133 & 1519894 & 2168 & 3 \\
\cline { 2 - 6 } & HWCL 17 & 577893 & 1520105 & 2158 & 3 \\
& HWCL 50 & 578224 & 1519779 & 2163 & 4 \\
\cline { 2 - 6 } & HWC 22 & 577981 & 1520162 & 2155 & 4 \\
\cline { 2 - 6 } & HHP 24 & 578956 & 1520251 & 2181 & 3 \\
\cline { 2 - 6 } & HHP 27 & 577485 & 1519618 & 2158 & 3 \\
\hline
\end{tabular}

\subsection{Sampling}

10 water samples 7 from HDW (Fig. 2A) and 3 from ponds (Fig. 3B) were collected from the pre-decided sites (Table 2). At the same sites, 30 soil samples were also collected 3 each from 10 pits excavated in the irrigated land that is irrigated by using water from the same HDW and HHP (Fig. 3C). At each site 3 samples were collected up to a depth of $100 \mathrm{~cm}$ along profile at different intervals, $0-20 \mathrm{~cm}, 20-60 \mathrm{~cm}$ and $60-100 \mathrm{~cm}$. All the samples were air dried, packed 
and sent to laboratory for analysis. From each site, data related to the condition of the irrigable lands, vegetation cover and type were recorded in addition to assessing the accumulation of external solonchacks indicators at the surface of the soils.

\subsection{Sample analysis and Data processing}

Water samples were analyzed for major cations $\left(\mathrm{Na}^{+}, \mathrm{Ca}^{2+}, \mathrm{Mg}^{2+}\right.$ and $\left.\mathrm{K}^{+}\right)$and anions $\left(\mathrm{HCO}_{3}{ }^{-}\right.$, $\mathrm{CO}_{3}{ }^{2-}, \mathrm{Cl}^{-}$and $\mathrm{SO}_{4}{ }^{2-}, \mathrm{NO}_{3}{ }^{-}$) and also for $\mathrm{pH}$ and electrical conductivity (EC) in the geochemical laboratory, Department of Earth Science, Mekelle University. Major cations were determined using both Flame Photometer and Atomic Absorption Spectrophotometer (AAS); $\mathrm{Cl}^{-}, \mathrm{SO}_{4}{ }^{2-}$ and $\mathrm{NO}_{3}^{-}$using Ultraviolet spectrophotometer; and $\mathrm{HCO}_{3}{ }^{-}$and $\mathrm{CO}_{3}{ }^{2-}$ using titration method. On the basis of $0.1 \mathrm{~N} \mathrm{HCl}$ used in the titration, alkalinity is calculated. Further, alkalinity data is used to determine the bicarbonate and carbonate ions using $\mathrm{pH}$ of water (Deutsch, 1997).

$\mathrm{CaCO}_{3}(\mathrm{mg} / \mathrm{l})=\left[\frac{\operatorname{TVS}(\mathrm{ml})-\mathrm{TVB}(\mathrm{ml}) * N * 50000}{\text { Volumeofsamples }(\mathrm{ml})}\right]$

Where, TVS= titration volume of samples; TVB=titration volume of blank; $\mathrm{N}=$ Normality.

The air dried soil samples were sieved to obtain $2 \mathrm{~mm}$ size fraction and were treated with double distilled water in the ration of 1soil: 5water ratio for measuring EC and 1soil:10 water ratio for $\mathrm{pH}$ using EC meter and $\mathrm{pH}$ meter, respectively. The aliquots were aspirated into flame photometer to analyse sodium $\left(\mathrm{Na}^{+}\right)$and potassium $\left(\mathrm{K}^{+}\right)$at 589 and $765.8 \mathrm{~nm}$, respectively, and into AAS to analyse $\mathrm{Mg}^{+2}$ and $\mathrm{Ca}^{+2}$ at 422.7 and $288.2 \mathrm{~nm}$, respectively. $\mathrm{CO}_{3}{ }^{2-}$ and $\mathrm{HCO}_{3}{ }^{-}$ were measured by acid neutralization method using $0.1 \mathrm{NH}_{2} \mathrm{SO}_{4}$ with phenolphthalein and methyl-orange as indicators respectively. The analysis of chloride was conducted by titration of the extracts with $0.1 \mathrm{~N} \mathrm{AgNO}_{3}$ solution using potassium chromate. Sodium Adsorption Ratio (SAR) and Exchangeable Sodium Percentage (ESP) were calculated as suggested by Booker Tate (1991).

$$
S A R=\frac{\mathrm{Na}^{+}}{\sqrt{\frac{C a^{2+}+M g^{2+}}{2}}}
$$$$
E S P=\frac{100(0.01475 S A R-0.0126)}{0.01475 S A R+0.9874}
$$

AquaChem software, a fully integrated statistical package developed specifically for graphical and numerical analyses of aqueous geochemical data sets is used to process water geochemical 
data. Piper diagram is prepared to represent and compare water quality data in the area. The soil samples on the other hand were treated with simple statistics such as mean, correlation etc. The electrical balance (electro-neutrality) in terms of ions in water was calculated by comparing the sum of the equivalents of cations with the sum of the equivalents of the anions (Deutsch, 1997). It was done using the charge balance equations. Later these were used for all calculations involving equilibrium interactions between water and geological materials (Freeze et., 1979). The accuracy of water analysis data is estimated using balance error given by the following equation and the balance error is expressed in percentage.

Cations / Anions Balance $=\frac{\sum(\text { Cations, } \text { meq } / L)-\sum(\text { Anions, } \text { meq } / L)}{\sum(\text { Cations, } \text { meq } / L)+\sum(\text { Anions, } \text { meq } / L)}$

Water analysis normally considers a balance error acceptable when it is less than 5\% (Freeze et al., 1979 and Deutsch, 1997). Apart from HWR6, all hand-dug well and pond water samples are within the acceptable level (Tables 3 and 4).

\section{RESULTS}

\subsection{Water}

Many of the water samples were not clear in appearance and odor. Four hand-dug wells were turbid and had bad odor due to re-construction and maintenance for the purpose of expansion to develop more land and in the presence of plants and other materials. Presence of algae has attributed bad taste to water in all the ponds in addition to brown color due to soil erosion. The data for both anions and cations and other parameters are provided in table 3. The electrical conductivity values for water (ECW) from HDW ranges from 570 to 1358 with a mean value of $887 \mu \mathrm{S} / \mathrm{cm}$ and for pond from 150 to 695 with a mean value of $441 \mu \mathrm{S} / \mathrm{cm}$. Similarly, $\mathrm{pH}$ values vary from 7.7 to 7.9 for water from HDW and 6.7 to 8.3 from ponds (Table 3).

Among anions, bicarbonate dominant in the water from both hand dug-well and ponds. It, ranges from 236.13 to 669.34 with a mean of $423 \mathrm{mg} / \mathrm{l}$ in HDW and 91.77 to 194.08 (141 mg/l mean) in pond. The next dominant ion chloride ranges from 29.03 to 51.68 (41 mg/l mean) in HDW and in pond from 0.96 to 86.77 (431 mg/l mean). Similarly, $\mathrm{NO}_{3}{ }^{-}$values (as total nitrate) in HDW range from nil (in three samples) to 8.25 (2.8mg/l mean), while the same in the pond vary from 2.74 to 9.69 (6 mg/l mean). Sulphate vary from 6.2 to 53.2 (19 mg/l mean) (HDW) 
and nil to 10.0 (5.6 mg/l mean) (ponds). Carbonate ion concentrations on the other hand are very low and vary from 0.9 to 2.2 in HDW and nil to $2.8 \mathrm{mg} / \mathrm{l}$ in ponds (Table 3).

Table 3. Hand dug well and pond water sample data, Gergera Watershed.

\begin{tabular}{|l|l|l|l|r|r|r|r|l|r|r|r|r|}
\hline S.No. & Sample & $\mathrm{pH}$ & $\begin{array}{l}\mathrm{EC} \\
(\mu \mathrm{S} / \mathrm{cm})\end{array}$ & $\begin{array}{l}\mathrm{HCO}_{3}{ }^{2-} \\
(\mathrm{mg} / \mathrm{l})\end{array}$ & $\begin{array}{l}\mathrm{CO}_{3}{ }^{2-} \\
(\mathrm{mg} / \mathrm{l})\end{array}$ & $\begin{array}{l}\mathrm{Cl}^{-} \\
(\mathrm{mg} / \mathrm{l})\end{array}$ & $\begin{array}{l}\mathrm{SO}_{4}{ }^{2-} \\
(\mathrm{mg} / \mathrm{l})\end{array}$ & $\begin{array}{l}\mathrm{NO}_{3}{ }^{-} \mathrm{N} \\
\mathrm{mg} / \mathrm{l})\end{array}$ & $\begin{array}{l}\mathrm{Na}^{+} \\
(\mathrm{mg} / \mathrm{l})\end{array}$ & $\begin{array}{l}\mathrm{Ca}^{++} \\
(\mathrm{mg} / \mathrm{l})\end{array}$ & $\begin{array}{l}\mathrm{Mg}^{++} \\
(\mathrm{mg} / \mathrm{l})\end{array}$ \\
\hline \multicolumn{10}{|c|}{ Pond water } \\
\hline 1 & HHP24 & 7.6 & 480 & 194 & 0.4 & 35 & 10 & 3 & 7 & 84 & 2 \\
\hline 2 & HHP27 & 6.7 & 150 & 138 & 0.02 & 1 & 0.0 & 10 & 7 & 44 & 2 \\
\hline 3 & HHPC9 & 8.3 & 695 & 92 & 2.8 & 87 & 7 & 6 & 4 & 76 & 2 \\
\hline \multicolumn{10}{|c|}{} \\
\hline 4 & HWR19 & 7.9 & 812 & 375 & 1.4 & 52 & 6 & 0.0 & 18 & 112 & 17 \\
\hline 5 & HWR52 & 7.8 & 977 & 300 & 1.1 & 43 & 20 & 2 & 9 & 88 & 22 \\
\hline 6 & HWR53 & 7.8 & 1358 & 669 & 2.2 & 39 & 53 & 4 & 39 & 136 & 58 \\
\hline 7 & HWCL6 & 7.9 & 570 & 441 & 2.0 & 42 & 15 & 0.0 & 4 & 96 & 46 \\
\hline 8 & HWCL17 & 7.8 & 1214 & 619 & 1.8 & 35 & 22 & 0.0 & 29 & 132 & 46 \\
\hline 9 & HWCL50 & 7.7 & 630 & 236 & 0.9 & 49 & 9 & 6 & 4 & 84 & 14 \\
\hline 10 & HWC22 & 7.7 & 718 & 322 & 0.9 & 29 & 10 & 8 & 4 & 80 & 26 \\
\hline
\end{tabular}

Among cations, $\mathrm{Ca}^{2+}$ is the most dominant cation followed by $\mathrm{Mg}^{2+}, \mathrm{Na}^{+}$and $\mathrm{K}^{+}$. As $\mathrm{K}^{+}$values being very low they are not mentioned in the table. In HDW samples $\mathrm{Ca}^{2+}$ values vary from 80 to $136 \mathrm{mg} / \mathrm{l}$ with a mean values $104 \mathrm{mg} / \mathrm{l}$ and in pond samples ranges from 44 to $84 \mathrm{mg} / \mathrm{l}$ (mean $68 \mathrm{mg} / \mathrm{l}$ ). Similarly, $\mathrm{Na}^{+}$values in water from HDW range from 4.14 to $39.1 \mathrm{mg} / \mathrm{l}$ (mean 15 $\mathrm{mg} / \mathrm{l}$ ) and in pond from 4.1 to $6.9 \mathrm{mg} / \mathrm{l}$ (mean $6 \mathrm{mg} / \mathrm{l}$ ). $\mathrm{Mg}^{2+}$ on the other hand varies from 14.4 to $57.6 \mathrm{mg} / \mathrm{l}$ (mean $33 \mathrm{mg} / \mathrm{l}$ ) in HDW and do not shows any variation in pond where all samples shows the same value $2 \mathrm{mg} / \mathrm{l}$ (Table 2). Interestingly $\mathrm{Ca}^{2+}$ is the dominating ion in both HDW and pond water and followed by $\mathrm{Mg}^{2+}$ in HDW and $\mathrm{Na}^{+}$in pond water.

Further, the parameters like alkalinity and SAR were calculated using the data in table 3 and the chemical type of water was deduced using piper diagrams (Fig.3) and given in table 4. The calculated values for Alkalinity range from 7.7 to $7.9 \mathrm{mg} / \mathrm{l}$ of $\mathrm{CaCO}_{3}$ in $\mathrm{HDW}$ and from 6.7 to $8.3 \mathrm{mg} / \mathrm{l}$ of $\mathrm{CaCO}_{3}$ in pond samples. Similarly, the SAR values for water from HDW ranges from 0.09 to 0.55 and the pond water samples ranges from 0.02 to 0.13 . According to the piper diagram (Fig. 3), water samples from HDW are classified into different chemical types. They are $\mathrm{Ca}-\mathrm{Mg}-\mathrm{HCO}_{3}, \mathrm{Ca}-\mathrm{HCO}{ }_{3}$, and $\mathrm{Ca}-\mathrm{Mg}-\mathrm{HCO}_{3}-\mathrm{Cl}$. Among these, the dominant one is Ca$\mathrm{Mg}-\mathrm{HCO}_{3}$ type. Similarly pond water sample data suggest three different types such as Ca$\mathrm{HCO}_{3}$, Ca- $\mathrm{HCO}_{3}-\mathrm{Cl}$ and $\mathrm{Ca}-\mathrm{Cl}-\mathrm{HCO}_{3}$ but the common type being $\mathrm{Ca}-\mathrm{HCO}_{3}$ (Table 4). 


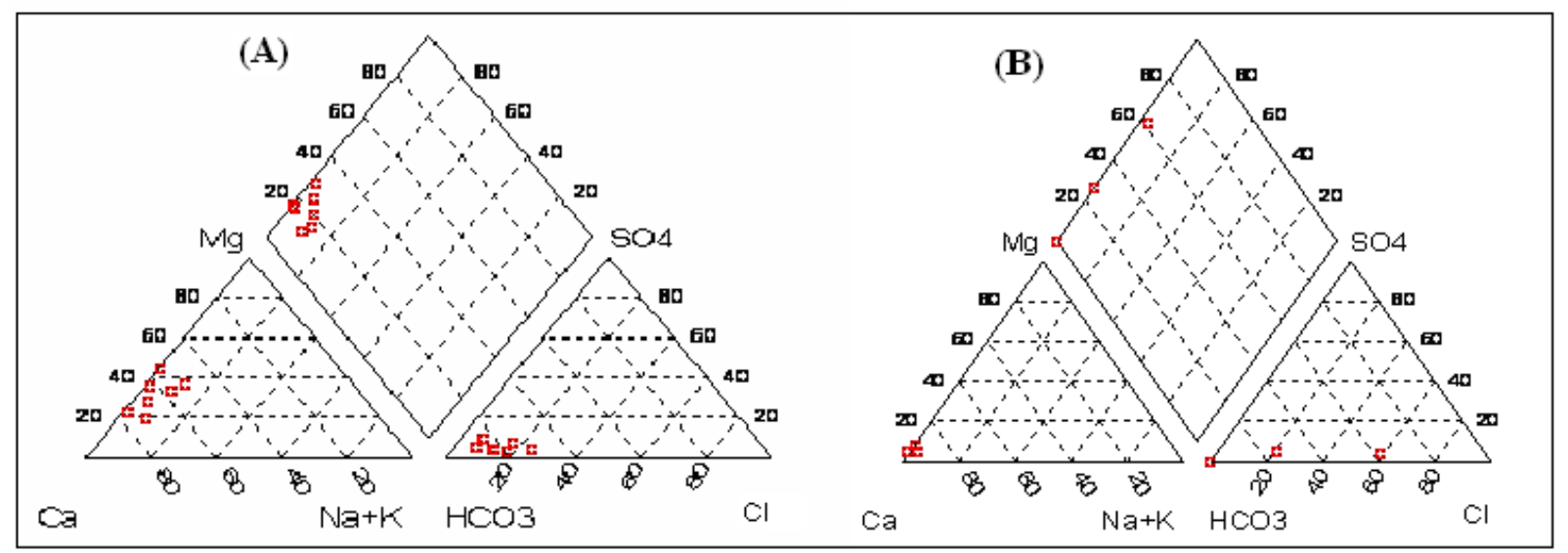

Figure 3. Piper diagram for both hand dug well (A) and pond (B) water sample data.

Table 4. Calculated values for alkalinity, SAR and chemical type of water for both HDW and pond samples, Gergera Watershed.

\begin{tabular}{|c|c|c|c|c|c|}
\hline S.No. & Sample & Alkalinity & Water type & SAR & $B E(\%)$ \\
\hline \multicolumn{6}{|c|}{ Pond water } \\
\hline 1 & HHP24 & 159.18 & $\mathrm{Ca}-\mathrm{HCO}_{3}-\mathrm{Cl}$ & 0.02 & 0.00 \\
\hline 2 & HHP27 & 113.05 & $\mathrm{Ca}-\mathrm{HCO}_{3}-$ & 0.02 & 0.00 \\
\hline 3 & HHPC9 & 75.35 & $\mathrm{Ca}-\mathrm{Cl}-\mathrm{HCO}_{3}-$ & 0.13 & 4.12 \\
\hline \multicolumn{6}{|c|}{ Hand dug well water } \\
\hline 4 & HWR19 & 361.77 & Ca-Mg-HCO ${ }_{3}^{-}$ & 0.09 & 1.57 \\
\hline 5 & HWR52 & 245.74 & Ca-Mg-HCO ${ }_{3}^{-}$ & 0.23 & 0.00 \\
\hline 6 & HWR53 & 548.98 & Ca-Mg-HCO ${ }_{3}^{-}$ & 0.71 & 0.00 \\
\hline 7 & HWCL6 & 307.53 & Ca- $\mathrm{HCO}_{3}^{-}$ & 0.41 & 5.54 \\
\hline 8 & HWCL17 & 507.86 & Ca-Mg-HCO ${ }_{3}^{-}$ & 0.55 & 3.94 \\
\hline 9 & HWCL50 & 193.67 & Ca-Mg-HCO- ${ }_{3}^{-} \mathrm{Cl}$ & 0.11 & 0.00 \\
\hline 10 & HWC22 & 265.16 & $\mathrm{Ca}-\mathrm{Mg}-\mathrm{HCO}_{3}^{-}$ & 0.10 & 0.00 \\
\hline
\end{tabular}

\subsection{Soil}

The data generated for 24 soil samples from 8 pits are presented in table 3. Electrical conductivity values at $25^{\circ} \mathrm{C}$ for soil samples from HDW irrigated land varied from 17 and $1445 \mu \mathrm{S} / \mathrm{cm}$ and the same in the soil from pond water irrigated land ranges from 51 to 1734 $\mu \mathrm{S} / \mathrm{cm}$. EC values for soils from hand dug-well water irrigated land in general are lower compared to soil from pond water irrigated land. In the case of $\mathrm{pH}$, soil related to HDW is slightly acidic (6.5 to 8.0) (Fig 4A \& B) compared to pond related soil which is slightly basic (7.5 to 8.2) (Fig 4C \& D). Interestingly, both EC and $\mathrm{pH}$ values decrease downwards with depth (Tables 5 and 6). Among major anions, sulphate values are higher compared to others in both types of soil. It is followed by chloride and bicarbonate and carbonate. However, carbonate is almost nil in many samples. 
Table 5. Soil data from hand dug wells, Gergera Watershed.

\begin{tabular}{|c|c|c|c|c|c|c|c|c|c|c|c|c|c|c|c|}
\hline \multicolumn{2}{|c|}{ Soil sample } & \multirow{2}{*}{$\begin{array}{l}E C \\
\mu S / c m \\
(1: 2.5) \\
\end{array}$} & \multirow[t]{2}{*}{$T^{o}$} & \multirow{2}{*}{$\begin{array}{l}p H \\
(1: 5)\end{array}$} & \multirow[t]{2}{*}{$T^{0}$} & \multirow[t]{2}{*}{$\mathrm{Na}^{+}$} & \multirow[t]{2}{*}{$\mathrm{Ca}^{+2}$} & \multirow[t]{2}{*}{$\mathrm{Mg}^{+2}$} & \multirow[t]{2}{*}{$\boldsymbol{K}^{+}$} & \multirow{2}{*}{$\frac{\mathrm{SO}^{-2}{ }_{4}}{\mathrm{mg} / \mathrm{l}}$} & \multirow[t]{2}{*}{$\mathrm{Cl}^{-}$} & \multirow[t]{2}{*}{$\mathrm{HCO}_{3}{ }^{2-}$} & \multirow[t]{2}{*}{$\mathrm{CO}_{3}{ }^{2-}$} & \multirow[t]{2}{*}{$S A R$} & \multirow[t]{2}{*}{ ESP } \\
\hline & & & & & & & & & & & & & & & \\
\hline \multirow[t]{3}{*}{ HWR19 } & -a & 68 & 20 & 7.6 & 21 & 5.5 & 4.2 & 2.2 & 3.1 & 16.0 & 7 & 0.4 & 0 & 0.47 & -0.57 \\
\hline & $-b$ & 17 & 20 & 7.3 & 21 & 4.6 & 8.2 & 1.3 & 1.2 & 14.4 & 14 & 0.2 & 0 & 0.4 & 0.67 \\
\hline & $-\mathrm{C}$ & 51 & 23 & 7.3 & 23 & 11.5 & 9.2 & 1.7 & 1.2 & 19.2 & 21 & 0.2 & 0 & 0.91 & 0.08 \\
\hline \multirow[t]{3}{*}{ HWR52 } & $-\mathrm{a}$ & 408 & 23 & 7.1 & 23 & 6.9 & 9.2 & 1.7 & 6.2 & 13.9 & 15.8 & 0.3 & 0 & 0.55 & -0.05 \\
\hline & $-b$ & 68 & 21 & 7.2 & 21 & 9.7 & 10.8 & 2.2 & 2.3 & 15.8 & 21 & 0.3 & 0 & 0.7 & -0.23 \\
\hline & $-\mathrm{C}$ & 68 & 22 & 6.9 & 23 & 7.6 & 9.6 & 2.0 & 2.0 & 17.3 & 24.5 & 0.1 & 0 & 0.58 & -0.41 \\
\hline \multirow[t]{3}{*}{ HWR53 } & $-\mathrm{a}$ & 51 & 23 & 8 & 23 & 15.2 & 10.0 & 1.7 & 2.3 & 23.0 & 21 & 0.4 & 0 & 1.16 & 0.45 \\
\hline & $-b$ & 34 & 23 & 7.6 & 23 & 15.2 & 2.0 & 1.2 & 3.9 & 13.9 & 21 & 0.4 & 0 & 1.27 & 0.61 \\
\hline & $-\mathrm{C}$ & 34 & 20 & 7.1 & 21 & 10.0 & 9.0 & 1.2 & 3.1 & 19.2 & 10.5 & 0.3 & 0 & 1 & 0.48 \\
\hline \multirow[t]{3}{*}{ HWCL6 } & $-a$ & 51 & 21 & 7.5 & 21 & 3.9 & 20.0 & 1.2 & 0.8 & 16.3 & 12.6 & 0.4 & 0 & 0.23 & -0.93 \\
\hline & $-b$ & 51 & 20 & 7.1 & 21 & 9.7 & 6.4 & 1.3 & 3.9 & 13.4 & 21 & 0.1 & 0 & 0.91 & 0.08 \\
\hline & $-c$ & 34 & 23 & 7.0 & 22 & 4.4 & 5.0 & 1.4 & 1.2 & 13.9 & 8.75 & 0.2 & 0 & 0.44 & -0.61 \\
\hline \multirow[t]{3}{*}{ HWCL17 } & $-\mathrm{a}$ & 34 & 22 & 7.6 & 23 & 5.8 & 10.4 & 1.7 & 2.0 & 21.8 & 17.5 & 0 & 0 & 0.43 & -0.63 \\
\hline & $-b$ & 34 & 20 & 7.0 & 21 & 11.7 & 9.6 & 1.4 & 4.3 & 13.4 & 21 & 0.3 & 0 & 0.93 & 0.11 \\
\hline & $-\mathrm{C}$ & 34 & 20 & 6.9 & 21 & 10.4 & 7.4 & 2.6 & 3.9 & 12.0 & 28 & 0.2 & 0 & 0.83 & -0.04 \\
\hline \multirow[t]{3}{*}{ HWCL50 } & $-\mathrm{a}$ & 689 & 22 & 7.0 & 22 & 7.6 & 17.4 & 2.0 & 3.5 & 18.2 & 14 & 0.2 & 0.6 & 0.46 & -0.58 \\
\hline & $-b$ & 1445 & 23 & 6.5 & 23 & 11.0 & 9.6 & 2.8 & 8.2 & 13.9 & 7 & 0.3 & 0 & 0.52 & -0.49 \\
\hline & $-\mathrm{C}$ & 68 & 20 & 7.3 & 21 & 10.6 & 29.0 & 2.4 & 6.2 & 16 & 28 & 0.9 & 0 & 0.51 & -0.51 \\
\hline \multirow[t]{3}{*}{ HWC22 } & $-\mathrm{a}$ & 51 & 22 & 7.3 & 23 & 8.1 & 5.2 & 1.8 & 4.3 & 13.9 & 10.5 & 0.3 & 0 & 0.78 & -0.11 \\
\hline & $-b$ & 51 & 21 & 7.5 & 25 & 9.4 & 5.8 & 1.6 & 8.2 & 17.8 & 17.5 & 0.2 & 0 & 0.89 & 0.06 \\
\hline & $-c$ & 34 & 22 & 7.4 & 23 & 8.1 & 8.80 & 1.8 & 3.9 & 18.2 & 24.5 & 0.1 & 0 & 0.64 & -0.3 \\
\hline
\end{tabular}

Note: $(\mathrm{a}=$ from 0-20 cm depth, $\mathrm{b}=20-60 \mathrm{~cm}, \mathrm{c}=60-100 \mathrm{~cm}$; HWC =Hand dug well cement lined; HWCL = Hand dug well clay lined; HWR= Hand dug well rock lined)

Table 6. Soil data from ponds, Gergera Watershed.

\begin{tabular}{|c|c|c|c|c|c|c|c|c|c|c|c|c|c|c|}
\hline $\begin{array}{l}\text { Soil } \\
\text { sample }\end{array}$ & $\begin{array}{l}E C \\
\mu S / \mathrm{cm} \\
(1: 2: 5)\end{array}$ & $T^{o}$ & $\begin{array}{l}p H \\
(1: 5)\end{array}$ & $T^{0}$ & $\mathrm{Na}^{+}$ & $\mathrm{Ca}^{+2}$ & $\mathbf{M g}^{+2}$ & $\boldsymbol{K}^{+}$ & $\begin{array}{l}\mathrm{SO}_{4}^{-2} \\
\mathrm{mg} / \mathrm{l}\end{array}$ & $\mathrm{Cl}^{-}$ & $\mathrm{HCO}_{3}{ }^{2-}$ & $\mathrm{CO}_{3}{ }^{2-}$ & SAR & ESP \\
\hline HHP24 - a & 68 & 22.1 & 8.0 & 23.2 & 14.6 & 9.4 & 1.1 & 2.0 & 7.2 & 10.5 & 0 & 24 & 0.89 & 0.53 \\
\hline$-b$ & 68 & 21.9 & 8.2 & 23.2 & 8.7 & 20.8 & 1.1 & 1.2 & 52.3 & 7 & 6.1 & 9 & 0.64 & -0.32 \\
\hline$-c$ & 51 & 22.6 & 8.3 & 23.5 & 3.2 & 20.0 & 0.8 & 0.1 & 14.9 & 7 & 6.1 & 12 & 0.19 & -0.99 \\
\hline HHP27 - a & 612 & 22.5 & 7.5 & 23.1 & 9.7 & 13.0 & 2.4 & 3.9 & 7.7 & 35 & 18.3 & 0 & 0.65 & -0.30 \\
\hline$-b$ & 561 & 22.2 & 7.7 & 22.9 & 11.3 & 7.6 & 2.2 & 5.9 & 19.2 & 35 & 0 & 0 & 0.53 & -0.48 \\
\hline$-c$ & 918 & 21.9 & 7.2 & 22.7 & 11.5 & 8.0 & 1.1 & 3.1 & 20.6 & 7 & 36.6 & 0 & 0.94 & 0.13 \\
\hline HHPC9 - a & 952 & 22 & 7.8 & 22.9 & 8.1 & 15.0 & 2.2 & 5.1 & 19.2 & 14 & 30.5 & 0 & 0.51 & -0.51 \\
\hline$-b$ & 1326 & 22.1 & 7.8 & 23.1 & 12.0 & 28.8 & 1.7 & 4.3 & 26.4 & 28 & 36.6 & 0 & 0.59 & -0.39 \\
\hline$-C$ & 1734 & 21.9 & 7.7 & 22.5 & 11.5 & 9.0 & 1.3 & 2.3 & 15.8 & 17.5 & 24.4 & 0 & 0.94 & -0.13 \\
\hline
\end{tabular}

Note: ( $\mathrm{a}=$ from $0-20 \mathrm{~cm}$ depth, $\mathrm{b}=20-60 \mathrm{~cm}, \mathrm{c}=60-100 \mathrm{~cm}$; HHP= Pond plastic lined; HHPC = Pond cement lined). 


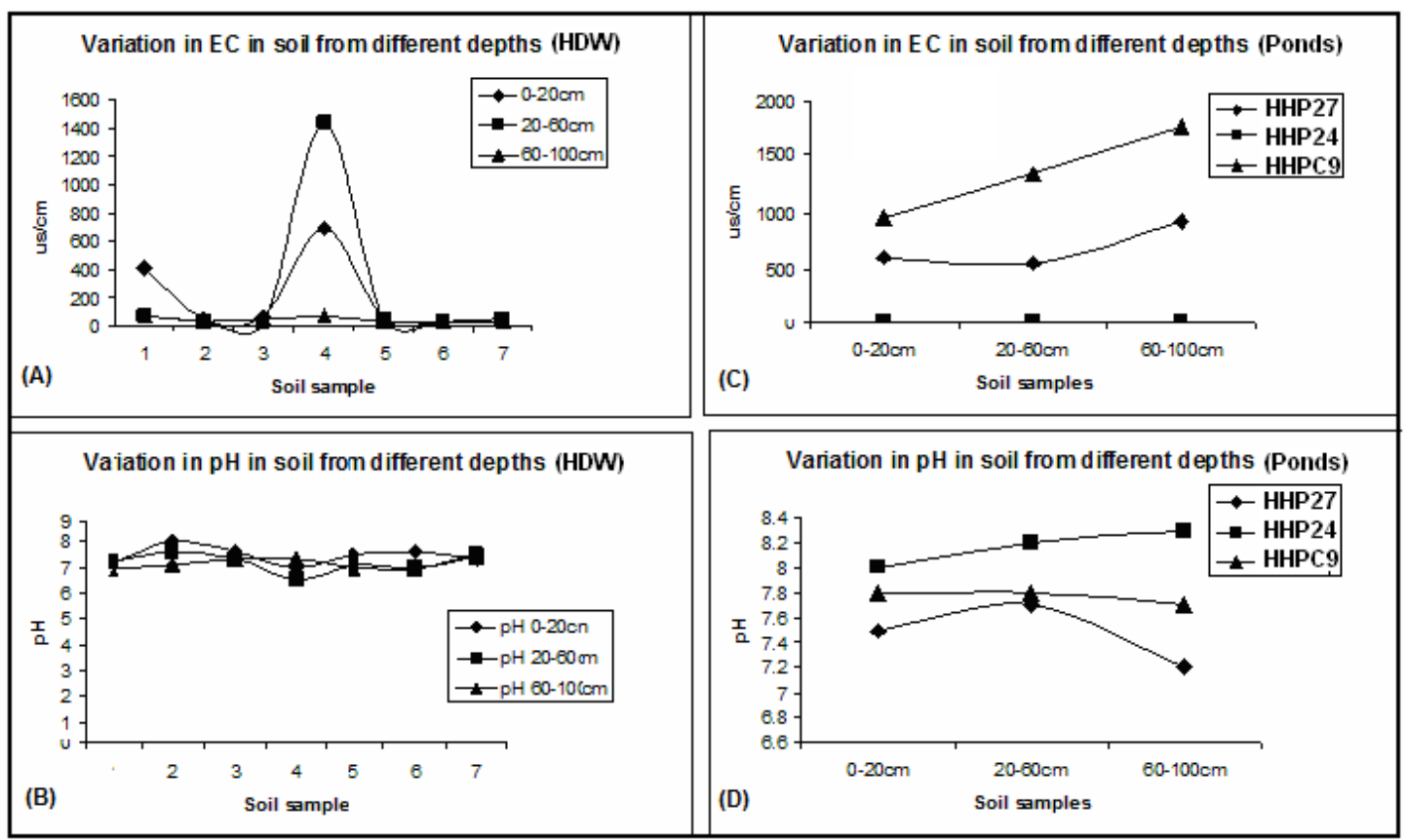

Figure 4. Depth-wise variation of EC, pH in soil related to HDW and Ponds.

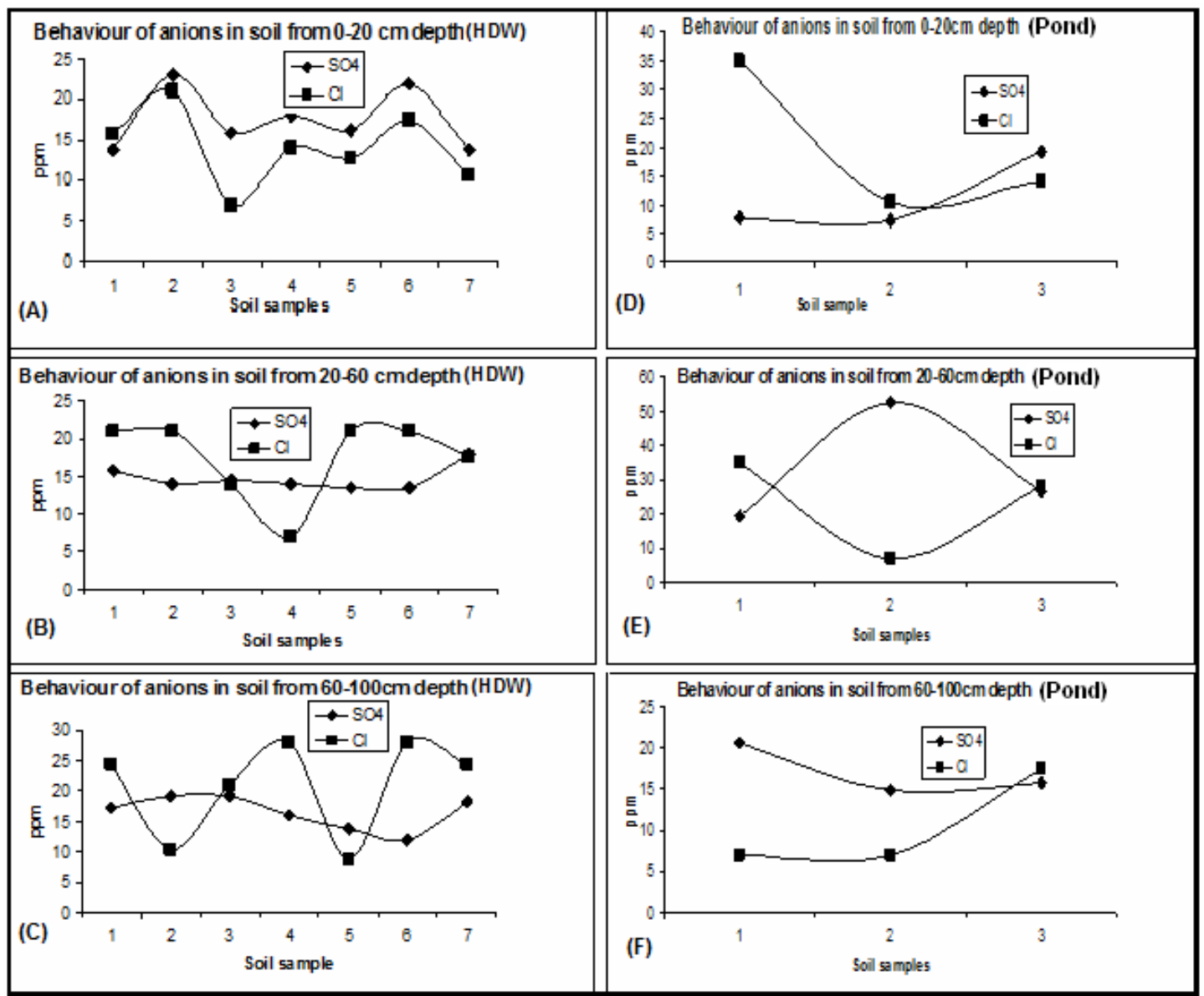

Figure 5. Depth-wise variation of sulphate and chloride in soil related to HDW and ponds. 


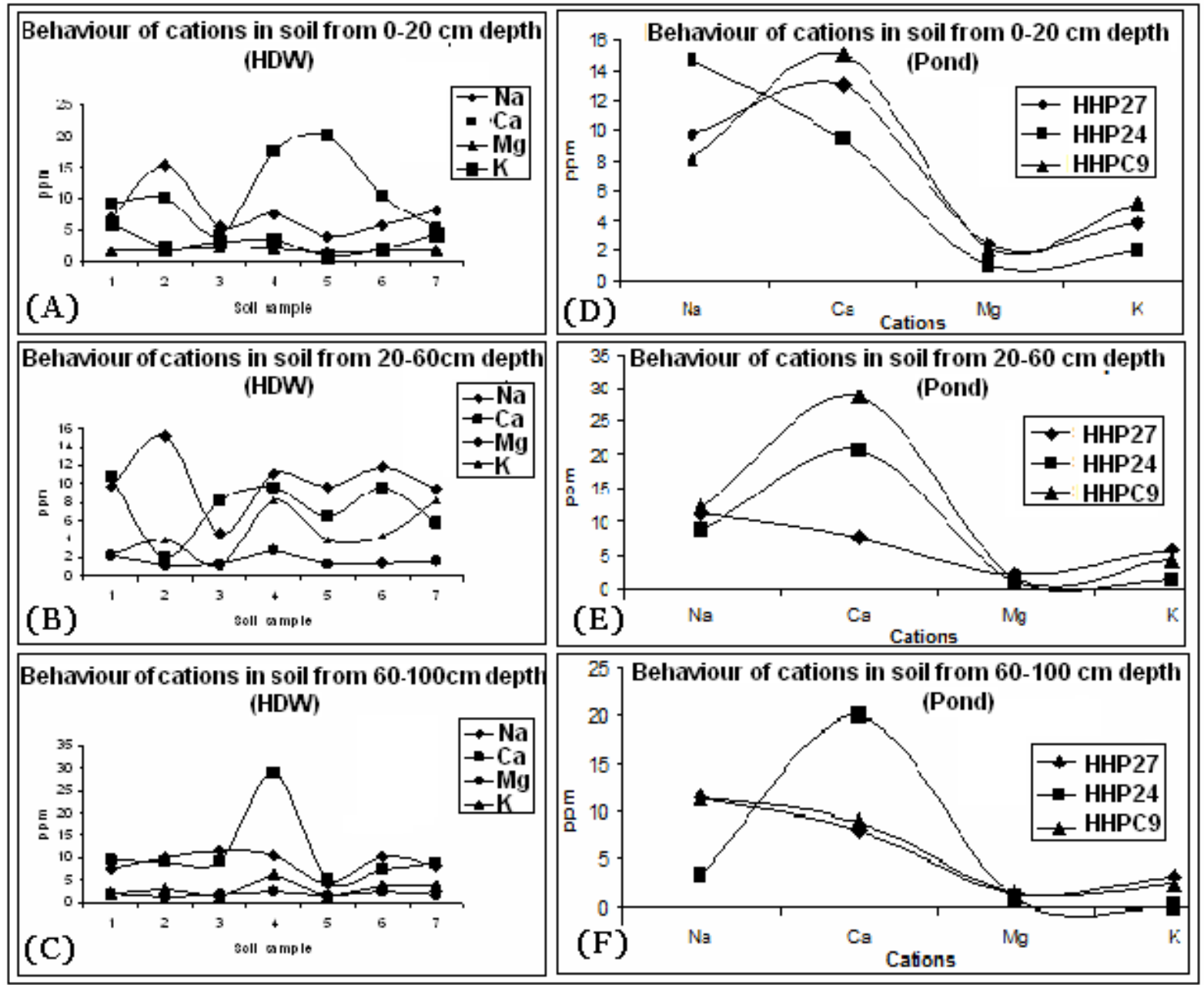

Figure 6. Depth-wise cations variation in soil related to HDW and ponds.

Sulphate values are lower in HDW soil (12 to $23 \mathrm{mg} / \mathrm{l}$ ) compared to pond-related soil (7.2 to $52.3 \mathrm{mg} / \mathrm{l}$ ) (Fig. 5) and in both the cases no clear trend is observed with depth. Chloride also shows similar trend like sulphate indicating higher values for pond- associated soil (7 to 35 mg/l) compared to HDW -associated soil (7-28 mg/l) and do not show any clear trend with depth (Fig. 5). Bicarbonate on the other hand shows downward decrease in concentration in both HDW (nil to $0.9 \mathrm{mg} / \mathrm{l}$ ) and pond-related soil (nil to $36.6 \mathrm{mg} / \mathrm{l}$ ). Relatively pond -related soils show higher values compared to that of HDW. Carbonate is almost nil in many samples except in one soil sample that is associated with pond in which the values range from 9 to 24 $\mathrm{mg} / \mathrm{l}$ and also show lower values with depth.

In the case of major cations, calcium is the dominant ion followed by sodium, potassium and magnesium (Fig. 6). Calcium concentrations range from 2 to $29 \mathrm{mg} / \mathrm{l}$ (HDW- soil) and 7.6 to 
$28.8 \mathrm{mg} / \mathrm{l}$ (pond-soil). Similarly, sodium values vary from 3.9 to $15.2 \mathrm{mg} / \mathrm{l}$ (HDW-soil) and 3.2 to $14.6 \mathrm{mg} / \mathrm{l}$ (pond-soil). Potassium though negligible in water, in soil it vary from 0.8 to 8.2 $\mathrm{mg} / \mathrm{l}$ (HDW-soil) and 0.1 to $5.9 \mathrm{mg} / \mathrm{l}$ (pond-soil). Magnesium is very low among cations and range from 1.2 to $2.8 \mathrm{mg} / \mathrm{l}$ (HDW-soil) and 0.8 to $2.4 \mathrm{mg} / \mathrm{l}$ (pond-soil) in soil. All the cations except sodium (to some extent) do not show any particular trend with depth. The sodium absorption ratio (SAR) in soil is higher than the water. In soil from HDW irrigated land the values range from 0.23 to 1.27 and in soil from pond-associated soil it vary from 0.19 to 0.94 .

\section{DISCUSSION}

Soil quality being one of the important factors that affects the production to a significant extent, hence keeping the quality to the required levels is always a matter of concern. Some of the reasons for such a change in the soil quality could be i) quality of water, ii) nature of the soil, iii) type and pattern of crops, iv) fertilizers and v) environmental conditions in the area. Water being one of the major reasons to influence soil quality, a detailed chemical data of water that is being used is essential to note whether it is suited for irrigation purpose or not. In the present case as both surface and groundwater are being used for irrigation purpose, the impact of these on soil quality and crop production is expected to be different.

\subsection{Water Salinity and Sodicity}

The salt concentration generally measured by determining the electrical conductivity of water indicates that the pond waters are not hazardous as their values are below $0.7 \mathrm{dS} / \mathrm{m}$ (Table 3). Hence there is no restriction on its use. In the case of hand dug wells out of seven, only in two samples EC values are below $0.7 \mathrm{dS} / \mathrm{m}$. In the remaining samples it ranges from 0.718 to 1.358 $\mathrm{dS} / \mathrm{m}$ (Table 3). Therefore, based on electrical conductivity values, two types of groundwater are recognized in the watershed: a groundwater that is not hazardous and needs no restriction on use and a groundwater that needs slight to moderate degree of restriction on use. The first type groundwater can be used for irrigation for almost all crops and for almost all kinds of soils. No soil or cropping problems will rise. Very little salinity may develop which may require slight leaching; but it is permissible under normal irrigation practices except in soils of extremely low permeabilities. To achieve a full yield potential using the second type, gradually increasing care in selection of crop and management alternatives are required. Interestingly, the 
rock and clay lined are showing higher values than the water from cement lined wells. Similar trend is also observed for water from cement-lined ponds.

SAR ( 0.02 to 0.13 ) and EC ( 0.7 to $0.2 \mathrm{dS} / \mathrm{m}$ ) values of pond water indicate that the waters needs slight to moderate degree of restriction on use. SAR values of HDW water (0.09 to 0.71) lie within 0-3 category of SAR, but based on EC, HDW water are categorized into two groups i.e. samples with $>0.7 \mathrm{dS} / \mathrm{m}$ (HWR19, HWCL17, HWR52, HWC22, and HWR53) and $<0.7$ $\mathrm{dS} / \mathrm{m}$ (HWCL50 and HWCL6). Use of water belonging to the former group does not indicate any problem in terms of hazards of sodicity. However, slight to moderate degree of restriction is use is necessary in the case of water belonging to the later group.

\subsection{Toxicity Problems}

Irrigation crops dominantly grown in the area are tomatoes, hot pepper, onions, potatoes, cabbages, and maize. These crops generally do not get affected much even if there is variation in the soil and water quality parameters. However, chloride ion concentration is an important factor to be considered if treated effluent is used for irrigation. For this purpose, the concentrations should not be more than 70 to $100 \mathrm{mg} / \mathrm{l}$, if plants are irrigated by the surface irrigation method or by a sprinkler irrigation method (Ayers and Wescot, 1976). High chloride concentration disturbs the osmotic balance between plants and soil, which affect the growth of plants because most plants are sensitive to chloride salts. The waste material being the source of chloride, it is necessary to take precautions while using waste directly or indirectly in irrigation. In the watershed, the commonly used method is surface irrigation method and in both water and soil samples chloride values are $<4 \mathrm{meq} / \mathrm{l}$ and is well within the acceptable limits for irrigation (FAO, 1985). According to FAO (1985) chloride concentrations in surface irrigation should be below $4 \mathrm{meq} / \mathrm{l}$ and $3 \mathrm{meq} / \mathrm{l}$ for sprinkler irrigations. Thus there is no restriction in the use of water and soil in the area in terms of chloride.

\subsection{Soil Sodicity}

The SAR values for hand-dug wells, ponds and soil range from 0.19 to 1.27 while the exchangeable sodium percentage (ESP) results are below $1 \%$ (Tables $5 \& 6$ ). Soils with SAR values greater than 13 are usually considered sodic. According to USDA soil classification, soils showing electrical conductivity values $<2000 \mu \mathrm{S} / \mathrm{cm}$ (at $25^{\circ} \mathrm{C}$ ), ESP $<15 \%$, SAR $<13$ and 
$\mathrm{pH}<8.5$ are classified as normal soils. Therefore, on the basis of the results of the present study the soils of Gergera watershed are considered as normal soils (Fig 7).

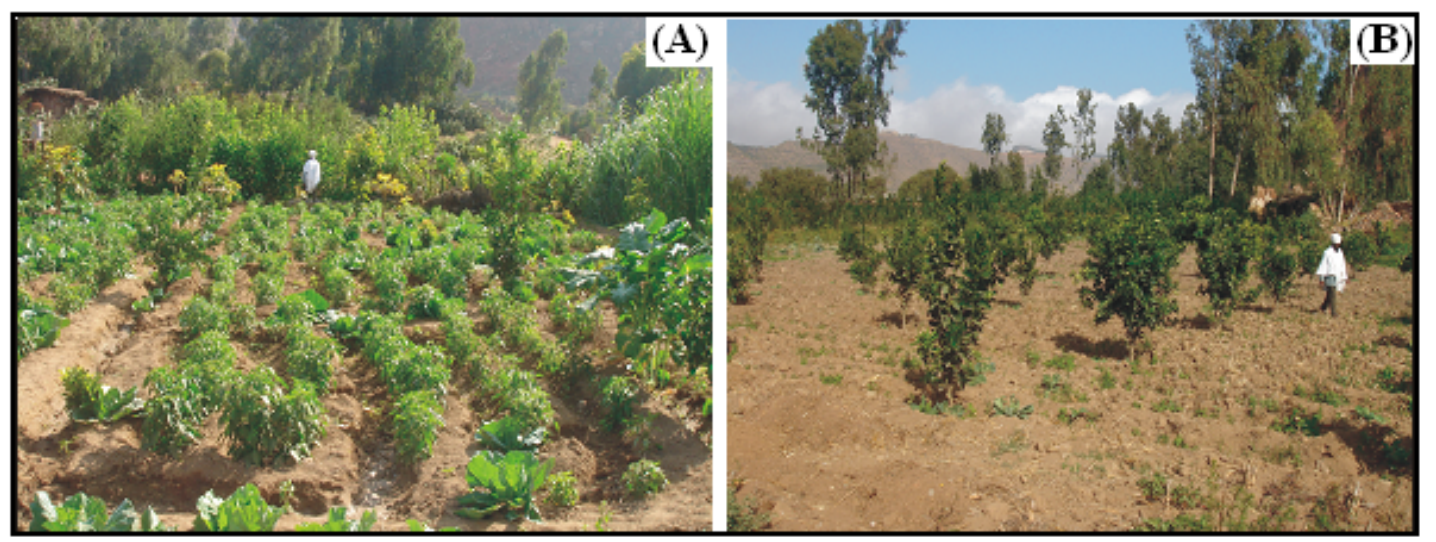

Figure 7. (A) Vegetables and (B) fruits grown by hand-dug wells, Gergera Watershed.

\section{CONCLUSIONS}

Generally, in the watershed the groundwater is suitable for irrigation purpose whereas utilization of surface waters for irrigation needs series of quality considerations. Though, soils are free from soil sodicity hazards, i) to achieve a full yield potential; ii) to sustain it for long period of time; iii) to avoid the possibility of increase in sodicity, and iv) to avoid the

possibility of occurrence of salinity and toxicity hazardous in future, proper irrigation scheme is required in the form of crop selection, fertilizer usage and suitable alternative management. In order to have sustainable soil and water resources use in Gergera watershed the following are recommended.

- Monitor the changes in water and soil quality over time;

- Adoption of community wells help to overcome wastage of land;

- The acid reacting fertilizers be replaced by local organic manure and compost for longterm land management and resource utilization;

- Impact of rock chemistry on water and soil quality needs to be investigated; and

- Suitable and affordable technologies like drip irrigation needs to be introduced.

\section{REFERENCES}

Ayers R.S \& Westcot D.W. 1976. Water quality for agriculture. FAO Irrigation and Drainage Paper 29, FAO, Rome, 97 p. 
Ministry of Water Resources. 2001. Initial national communication of Ethiopia to the UN Framework Convention on Climate Change (UNFCCC). Report submitted to the conf. of parties of UNFCCC under GEF supported Climate Change Enabling Activities Project of Ethiopia, Addis Ababa.

FAO. 1985. Water quality for agriculture. FAO, Rome.

FAO. 2001. Smallholder irrigation technology: prospects for Sub-Saharan Africa. http://www.fao.org/documents/show_cdr.asp?url_file=/docrep/004/y0969e/yㅁ69e00 (accessed date 11/7/2005).

FAO. 2005. Low-cost water pumps to boost food security produced by IPS in co-operation with the United Nations Food and Agriculture Organization. FAO, Rome.

Fitsum, H., Pender, J \& Nega, G. 2002. Land degradation and strategies for sustainable land management in Ethiopian highlands. Tigray. $2^{\text {nd }}$ Ed., Socio-economics and policy research working paper 25, Nairobi, Kenya.

Mekuria, T. 2003. Small Scale Irrigation for Food Security in Sub- Saharan Africa. Report and Recommendation of CTA Studies, Jan.20-29, Ethiopia, www.cta.int/pubs/wd8031.pdf (access: 11/09/2008).

REST. 1997. Wereda based integrated development program. Unpublished report, Mekelle, Ethiopia.

Siegfried P., Fantu, C., Stefan, B \& Eshetu, C. 1990. Ethiopia rural development option, Zed books Ltd, 57 Caledonian Rd, London. 